\section{Cornish Promontory Forts}

INTEREST in the promontory forts of Cornwall has been much stimulated by the results of Dr. Mortimer Wheeler's excavations in Brittany. Ono of them, the large and evidently important fort of Trevelgue Head and Porth Island, Newquay, has been under excavation since July 3 . Its investigation is being carried on under the direction of Mr. C. K. Croft Andrew on behalf of the Cornwall Excavations Committeo. Excavation is still in progress, though much hampered through lack of funds; but the finds reported to date (The Times, Aug. 15), ranging from Neolithic to Early Iron Age, fully bear out anticipation of the importance of the site, based partly on its superficial resemblance to Hengistbury Head, Hampshire, partly on the imposing character of its septuple line of defences. The main defences are now assigned to the third century B.C., when there supervened an occupation rich in artistic and metallurgical attainments. 'Tho pottery is akin to that of Glastonbury Lake Village, displaying curvilinear and lenticular decoration, as well as naturalistic leaf and vegetable forms. It would appear that in order that the outermost defences should include a native iron mine, they were given an eccentric form. At the back of tho sixth, the innermost, rampart was banked the refuse of a considerable Iron Ago town. This consisted of houses, or large huts, arranged terrace-wiso on the slope rising from the back of the sixth bank to the apex of the island. The best example of a house cleared as yet was occupied from about 200 B.c. to A.D. 100. It is nearly circular and $46 \mathrm{ft}$. across, tho upper sector being sunk two feet deep in the soft slate rock. It shows some fine examples of dry-walling. Tho wall was probably nover more than $4 \mathrm{ft}$. or $5 \mathrm{ft}$. high, but it was $6 \mathrm{ft}$. thick. Tho roof ran up from eaves which were supported on a ring of external posts, while the span, being too great for early carpenters, was supported by rings of inner posts.

\section{Radio for Short Distances}

THE use of ultra-short waves in radio transmission for keeping police cars in touch with headquarters has proved itself of great value. A.R.P. necessities are increasing the demand for this system of communication. There are also a number of uses to which it can be usefully employed in connexion with switching on and off street lamps, water heaters during peak loads, calling air raid wardens and firemen and there would still be space in the highfrequency band for further applications, which are sure to be suggested within the next few years. Had the cost of these installations not been so high the progress made would probably have been more rapid. Sudden changes in the temperature will also encourage the installation of load-controlling equipment. One of its most useful applications is in connexion with fire-fighting. Experience gained in a recent local blackout shows that ordinary telephone communications can break down under the stress of a sudden emergency. The Electrician of August 18 says the Post Office has allotted a limited range of frequencies in the ultra-short wave band for police and fire-brigade purposes and that experimental work is being carried out by the Post Office in association with the Homo Office to ascertain the possibility of developing local systems of this typo. In dealing with emergencies, speed of communication is of the highest importance and wherever it is feasible to provide an effective means by which police, fire-brigade and ambulanco headquarters can keep constantly in touch with their mobilo units, this should bo done.

\section{Broadcasting over the Power Mains}

Demonstrations have recently been made of the broadcasting of messages over the electric light and power mains. In 1927 the method was conceived by Captain P. P. Eckersley, who, at that time, thought that the B.B.C. should deal with this special trans. mission. There is no technical defect in the method. For example, a message can be sent from any sub. station to all the consumers with which it is connected. The messages traverse one of the underground mains and get back to earth by a leakage circuit which contains the signalling device. This system has the advantage that it can bo applied very readily. It needs no overhead wiring and so is less vulnerable to attack during a war. It could reach tho nino million people in Great Britain who are supplied by a company with electric lighting in their homes. If domestic telephones were used, only two million homes would be available. The following objection to the method has been urged by some engineers. It is said that in time of war or civil commotion, enemy agents could easily inject messages into a power mains system and that it would be difficult to locate where they wero working until the mischief had been done. Similarly, they might bo ablo to jam any official message to the public. Secing that power networks are sectionalized it is improbable that pirate messages would reach moro than two or three hundred people at most. If a telephone service wero used the number of listeners affected would be about the same as with the power mains system. In either case it would not be difficult to devise a method of locating and cutting off the offender. Electric supply engineers are quite enthusiastic about the broadcasting method. Captain Eckersley and Mr. W. B. Woodhouse are urging that a conference of all bodies interested should be called in order to decide, without further delay, what is best to bo dono.

\section{Vocational Training for Firemen}

A BuLcetre, "Vocational Training for Firemen" (Vocational Division Bulletin, No. 199, Trado and Industrial Series, No. 57. G.P.O., Washington, D.C. 10 cents) issued by the Office of Education, U.S. Department of the Interior, gives a general account of the present status of firemen training in the United States, particularly with reference to programmes developed in co-operation with public vocational education. The estimated loss by fire in the United States in 1937 was 285 million dollars, and the growing demands upon the fire servico have increased the importance of training all members of fire departments sufficiently to enable them to utilize 